\title{
PERKEMBANGAN REKAYASA GENETIKA DALAM BUDIDAYA IKAN HIAS DI INDONESIA
}

\author{
Eni Kusrini \\ Balai Penelitian dan Pengembangan Budidaya Ikan Hias \\ Jl. Perikanan No. 13, Pancoran Mas, Depok 16436 \\ E-mail: ennyperikanan@yahoo.com
}

\begin{abstract}
ABSTRAK
Teknologi rekayasa genetika transgenesis telah digunakan sejak 1980 dan sekarang berkembang memproduksi makhluk hidup dengan fenotip yang diinginkan. Di bidang akuakultur, telah dilakukan beberapa metode transgenik antara lain penggunaan vektor yang dinamakan replicationdefective pantropic retroviral (salah satu elemen vektor) untuk menginfeksi sel lines ikan. Perkembangan riset transgenik yang dilakukan sudah sampai tahapan dapat menghasilkan generasi pertama (F-1) yang masih membutuhkan verifikasi untuk mendapatkan keturunan-keturunan transgenik homozigot yang dapat digunakan untuk memproduksi massal ikan transgenik heterozigot hasil perkawinan dengan ikan normal. Teknik rekayasa genetika terus-menerus mengalami perkembangan dan penyempurnaan dari metodemetode sebelumnya. Adapun metode-metode yang telah berhasil diterapkan dalam teknologi transfer gen antara lain adalah mikroinjeksi, elektroporasi, dan transfeksi. Keberhasilan menghasilkan ikan hias transgenik melalui biologi molekuler dengan karakter keunggulan tertentu memberikan harapan baru dalam budidaya ikan khususnya dalam menunjang peningkatan kualitas warna dan bentuk. Meskipun rekayasa genetika bukan segala-galanya, karena adanya keterbatasan dalam menghasilkan ikan transgenik seperti badan yang bengkok, kepala bercabang, dan lain-lain.
\end{abstract}

\section{KATAKUNCl: rekayasa genetika, metode trans- fer gen, promotor}

\section{PENDAHULUAN}

Potensi kekayaan alam ikan hias Indonesia telah diakui secara internasional baik tawar maupun laut. Kekayaan keanekaragaman hayati ini semestinya menjadi kekuatan komperatif di berbagai sektor pembangunan ekonomi. Keanekaragaman hayati yang meliputi keanekaragaman ekosistem, keanekaragaman jenis, dan keanekaragaman jenis inilah merupakan potensi yang perlu dimanfaatkan secara berkelanjutan. Seiring dengan kemajuan ilmu pengetahuan dan teknologi terutama dengan perkembangan ilmu genetika dan bioteknologi modern, sumberdaya hayati telah dapat digunakan untuk menghasilkan sumber-sumber baru senyawa kimia, gen, varietas, dan produk bioteknologi lainnya baik untuk tujuan ilmiah maupun komersial. Pemanfaatan keanekaragaman hayati melalui bioteknologi modern atau yang dikenal sebagai rekayasa genetika memberi peluang untuk menunjang produksi pertanian, ketahanan pangan, dan peningkatan kualitas hidup manusia.

Beberapa puluh pangan transgenik saat ini telah beredar di pasaran. Para pakar rDNA telah mampu memotong atau mencopot suatu gen yang dikehendaki, dari individu hidup apa saja ke individu yang lain. Di bidang akuakultur, telah dilakukan beberapa metode transgenik antara lain penggunaan vektor yang dinamakan replication-defective pantropic retroviral untuk menginfeksi sel lines ikan, kadal air, kodok, dan nyamuk. Metode alternatif lainnya adalah transfer gen dengan bantuan sel. Teknik ini merupakan pengembangan dari metode mikroinjeksi, dengan pertimbangan bahwa untuk menghasilkan ikan transgenik membutuhkan banyak waktu, biaya, fasilitas, dan tenaga. Teknik ini telah berhasil diaplikasikan ke ikan rainbow trout dengan menggunakan sel bakal gonad yang membawa gen GFP. Namun demikian teknik ini masih memerlukan penelitian lebih lanjut untuk dapat diaplikasikan pada spesies ikan lainnya (Alimuddin et al., 2003).

Pada bidang akuakultur teknologi rekyasa genetika yang selama ini telah banyak digunakan untuk ikan-ikan konsumsi (salmon, nila, udang, patin, mas) ini berguna untuk meningkatkan laju pertumbuhan ikan, mengatur kematangan gonad, diferensiasi seks dan sterilitas; meningkatkan resistensi terhadap patogen, mengadaptasi ikan terhadap lingkungan baru (freeze resistance), merubah karakteristik biokimia dari daging ikan sehingga menciptakan rasa daging yang diinginkan, mengubah jalur 
metabolisme sehingga terjadi efisiensi pakan. Selanjutnya untuk ikan hias masih sedikit penelitian tentang rekayasa genetika tersebut. Target pada produksi ikan hias adalah berfokus pada penampilan baik bentuk, warna, maupun resisten penyakit.

\section{Keberhasilan Rekayasa Genetika Ikan}

Sejak tahun 2006, Indonesia telah mulai melakukan penelitian dasar di bidang bioteknologi yang berkaitan dengan pembentukkan ikan transgenik. Sebagian besar institusi yang melakukan aktivitas penelitian transgenik tersebut adalah institusi pemerintah baik yang termasuk lembaga penelitian pemerintah di bawah Badan Litbang Kelautan dan Perikanan (BPPI Sukamandi untuk ikan patin dan mas, BPPBAT Bogor untuk GH ikan gurami, BPPBAP Maros untuk udang windu, BPPBIH Depok untuk ikan hias), maupun di bawah ditjen teknis yaitu BBPBAT Sukabumi untuk mas dan lele, BBAP Situbondo untuk ikan kerapu) serta institusi riset di bawah koordinasi Menteri Negara Riset dan Teknologi seperti Badan Penerapan dan Pengkajian Teknologi (Bioteknologi Serpong), serta Perguruan Tinggi pemerintah (BDP-IPB).

Hingga saat ini fokus komoditas yang digunakan dalam kegiatan rekayasa genetik ikan di Indonesia meliputi jenis-jenis ikan air tawar sebagai berikut: ikan mas, nila, lele, patin, dan gurame. Untuk komoditas air ekosistem payau diwakili oleh udang windu, udang vaname, dan ikan kerapu. Secara umum perkembangan riset transgenik yang dilakukan sudah sampai tahapan dapat menghasilkan generasi pertama ( $F-1$ ) yang masih membutuhkan verifikasi untuk mendapatkan keturunanketurunan transgenik homozigot yang dapat digunakan untuk memproduksi massal ikan transgenik heterozigot hasil perkawinan dengan ikan normal. Dengan hasil yang diperoleh sejalan dengan perkembangan penelitian transgenik yang telah dilakukan di Indonesia, teknologi ini telah dikuasai mulai dari aktivitas isolasi gen, pembuatan kontruksi gen, penyisipan gen asing ke dalam ikan target. Namun demikian keberhasilan dan pengujian produk sebagaimana yang diharapkan masih membutuhkan pengujian lebih lanjut. Adapun gen-gen yang telah berhasil ditransfer pada ikan disajikan pada Tabel 1.

Karakter genetik yang dapat meningkatkan laju pertumbuhan, ketahanan terhadap suhu dingin dan penyakit, daya tahan terhadap gas oksigen terlarut rendah, dan efisiensi konversi pakan telah dicapai pada beberapa spesies ikan dan diintroduksikan terhadap ikan bernilai ekonomis penting sehingga menguntungkan. Di samping itu, membuat ikan dengan warna berbeda pada ikan zebra dengan menggunakan gen GFP (Green fluoroscent
Tabel 1. Gen-gen yang telah berhasil ditransfer ke ikan

\begin{tabular}{lll}
\hline \multicolumn{1}{c}{ Spesies } & Konstruksi gen & \multicolumn{1}{c}{ Daftar acuan } \\
\hline Goldfish & mM T/hGH & Zhu et al. (1985) \\
Trout & SV40/hGH & Chourrout et al. (1986) \\
Cathfish & mM T/hGH & Dunham \& Eash (1987) \\
Salmon & FAFP/fAFP & Fletcher et al. (1988) \\
Loach & mM T/hGH & Benyumov et al. (1989) \\
Medaka & FLus/fLuC & Tamiya et al. (1990) \\
Pike & RSV/bGH & Guise et al. (1991) \\
Common carp & mM T/hGH & Hernandez et al. (1993) \\
\hline
\end{tabular}

Sumber: Pinkert (1994)

protein), YFP (Yellow fluoroscent protein), dan RFP (Red fluoroscent protein) yang dapat terlihat pada kondisi cahaya biasa. Ikan zebra (Brachydanio rerio) biasanya berwarna perak dengan garis-garis hitam keunguan, dengan teknologi transgenik dapat memendarkan warna hijau atau merah pada tubuhnya (Gambar1). Warna tersebut diambil dari warna ubur-ubur yang disuntikan ke telur ikan zebra. Ikan jenis ini sebenarnya dirancang sebagai detektor adanya racun-racun yang ada di alam. Agar berfungsi sebagai indikator polusi, para pakar memasukkan gen pemicu yang akan mengaktifkan pancaran cahaya pada ikan apabila ikan berada dalam lingkungan yang mengandung zat tertentu. Menurut penelitian yang dilakukan oleh Zhiyuan Gong dari National University of Singapure, sejauh ini ikan-ikan zebra atau yang lebih populer disebut goldfish hasil rekayasa tersebut tidak menimbulkan ancaman terhadap lingkungan. Ikanikan ini hanya memancarkan warna terang di bawah segala macam sinar, namun tidak akan mencemari lingkungan. Meskipun sebenarnya ikan ini hanya mempunyai dua macam warna tambahan, namun dapat dikembangkan menjadi lima warna yang berbeda, di mana masing-masing warna tersebut akan bersinar sesuai dengan jenis polutan yang dijumpai ikan (Blake, 2007).

Keberhasilan yang lain yaitu mentransfer gen hormon pertumbuhan manusia ( $\mathrm{hGH}$ ) dengan promoter gen metallothionein mouse (mMT), ke dalam telur-telur ikan goldfish yang telah dibuahi. Selanjutnya rekayasa genetik juga dilakukan pada ikan-ikan medaka (Ozato et al., 1989), ikan catfish (Yan \& Özgünen, 1993), crayfish dan zebrafish (Tsai, 2008). Perkembangan teknik transfer gen di ikan bermula dari penggunaan mikroinjeksi (Zhu et al., 1985). Perkembangan selanjutnya sampai tahun 1990, transgenik ikan telah dilakukan pada 13 jenis ikan yaitu atlantic salmon, common carp, goldfish, loach, medaka, mud carp, northern pike, rainbow trout, silver crucian, nile tilapia, wuchang fish, dan zebra fish (Chen, 1994). Penelitian 


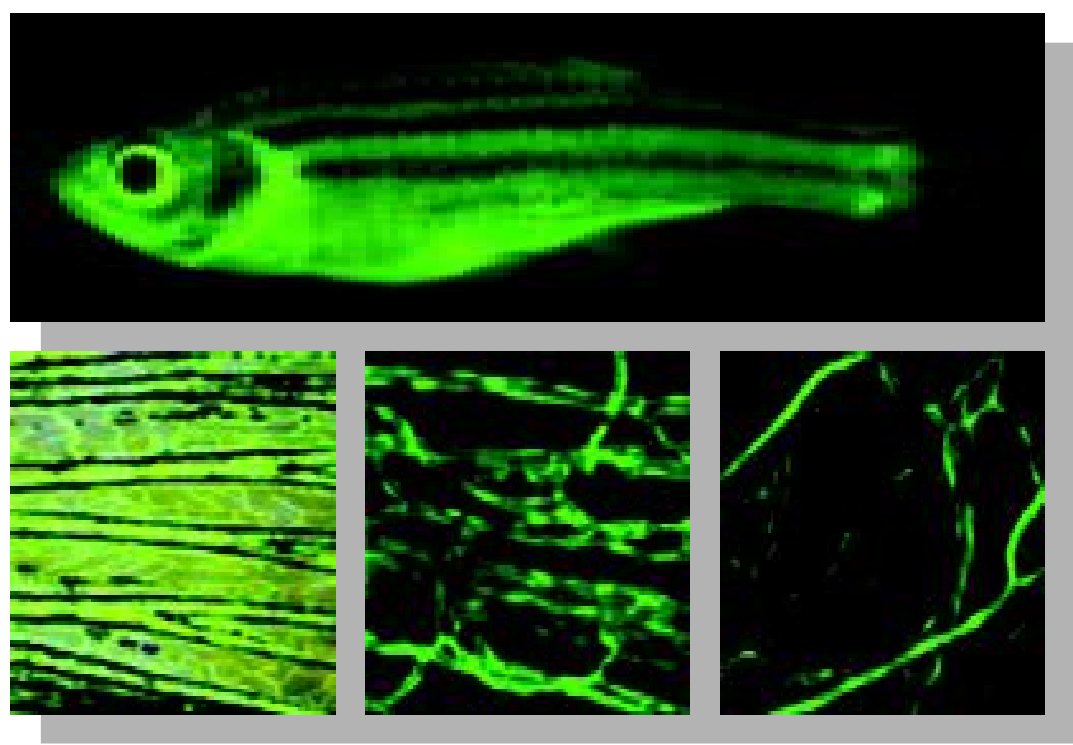

Gambar 1. Ikan zebra berpendar hijau hasil rekayasa genetika

pendahuluan terhadap ikan hias di Indonesia telah dilakukan dengan menggunakan model ikan komet dan diinsersi dengan green fluorescent protein (GFP) sebagai target yang diinginkan (Gambar 2). Transfer gen hasil rekombinan yang telah dimurnikan diinsersikan ke dalam masing-masing telur ikan komet, yang merupakan tahapan selanjutnya dapat dilakukan dengan beberapa metode.

\section{Prinsip Dasar Transfer Gen}

Teknologi transgenesis merupakan piranti yang sangat ampuh dalam menganalisis fungsi biologi molekuler dan dalam menghasilkan trait (karakter) penting yang komersial dalam akuakultur khususnya ikan hias. Teknologi transgenesis adalah suatu proses mengintroduksikan DNA eksogenous atau DNA asing ke hewan uji dengan tujuan untuk memanipulasi struktur genetiknya
(Glick \& Pasternak, 2003). Secara umum prinsip dasar transfer gen digambarkan dalam diagram pada Gambar 3. Adapun prinsip dasar teknik memproduksi ikan transgenik didasarkan kepada beberapa tahapan yaitu:

1. Penentuan ikan spesies; menurut Ozato et al. (1994), menyarankan penggunaan jenis ikan "model" sangat perlu untuk kepentingan pengembangan penelitian. Ikan yang digunakan mempunyai karakteristik ideal di antaranya; siklus hidup dan reproduksi pendek, dalam satu tahun dapat memijah beberapa kali; produksi telur, dan sperma ikan banyak.

2. Menyiapkan spesifik gen dengan spesifik produk dari gen tersebut yang diinginkan.

3. Isolasi DNA yang mengandung gen target atau gen of interest (GOI).
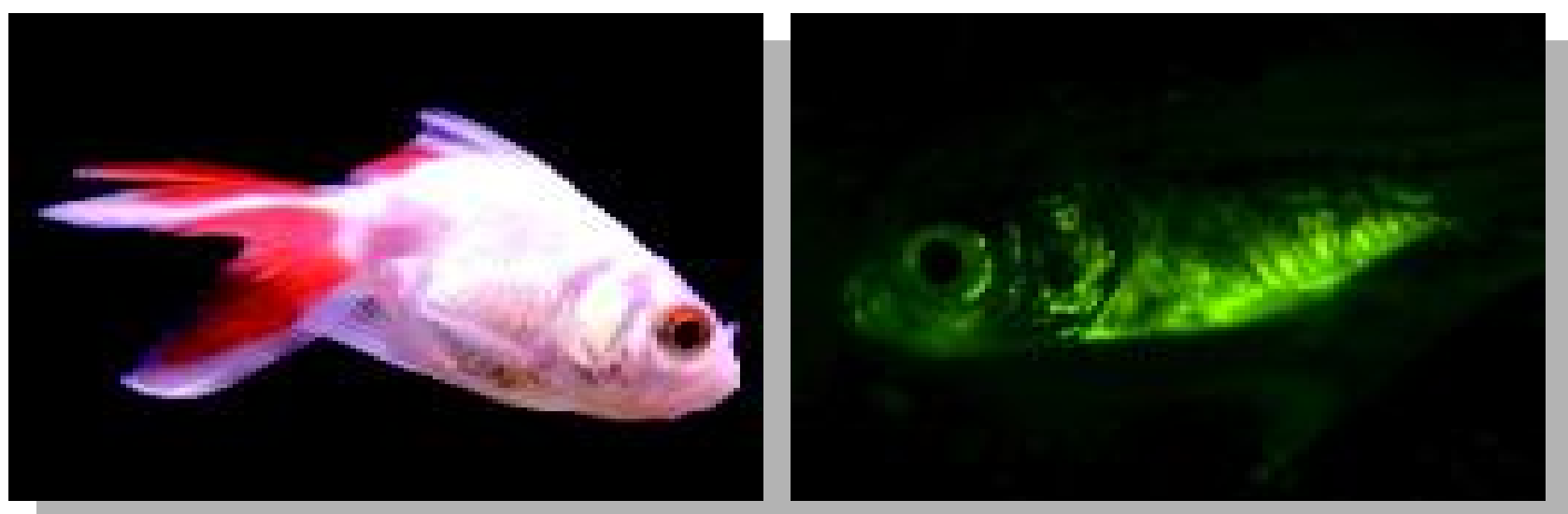

Gambar 2. Ikan komet sebelum diinsersi GFP (kiri) dan turunan F-1 ikan transgenik GFP (kanan) foto di bawah mikroskop flouresen 


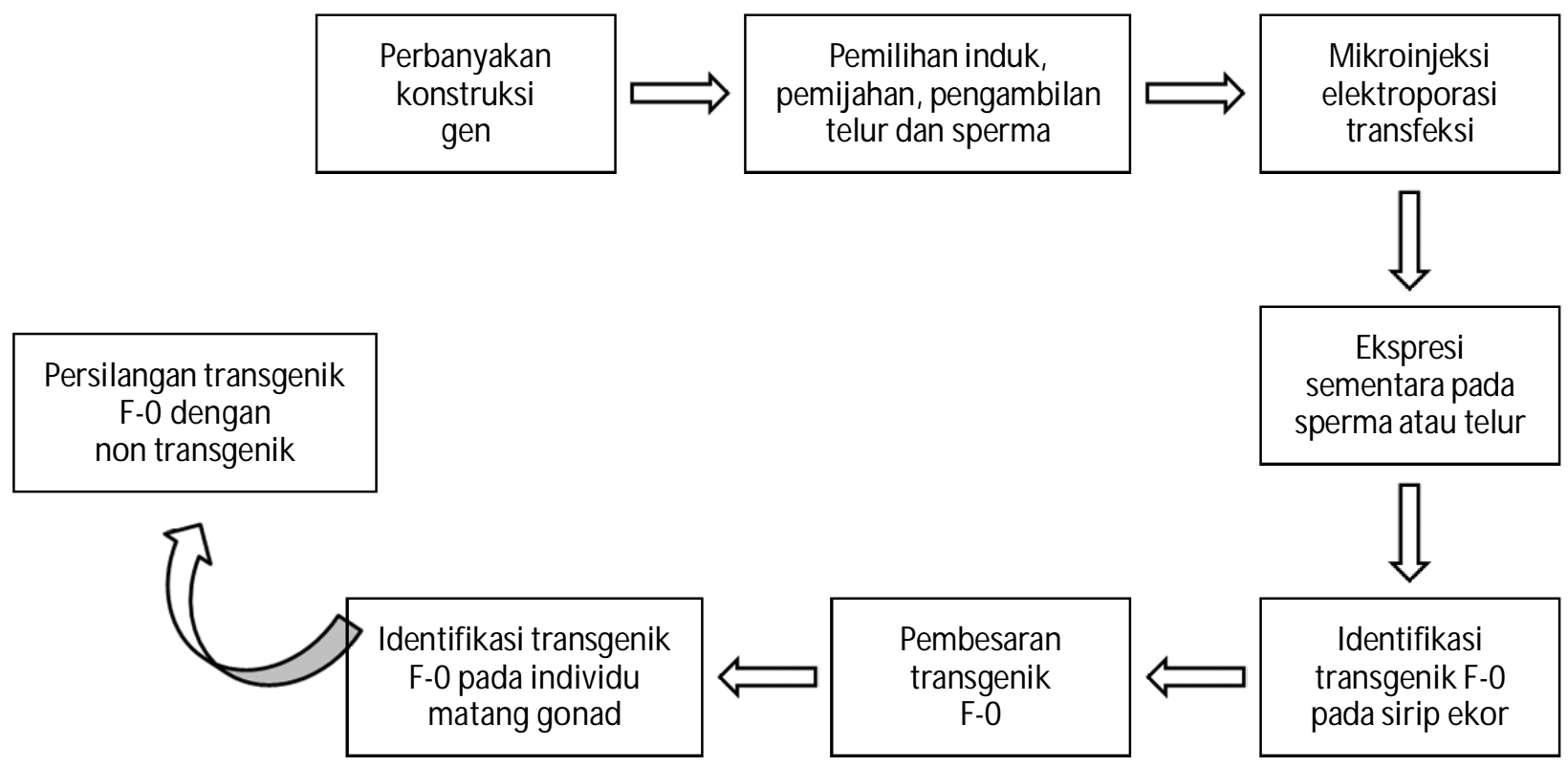

Gambar 3. Roadmap secara umum dasar-dasar transfer gen

4. Isolasi plasmid DNA bakteri yang akan digunakan sebagai vector.

5. Manipulasi sekuen DNA melalui penyelipan DNA ke dalam vektor. (a) pemotongan DNA menggunakan enzim restriksi endonuklease. (b) penyambungan ke vektor menggunakan DNA ligase.

6. Transformasi ke sel mikroorganisme inang

7. Pengklonan sel-sel dan gen asing.

8. Identifikasi sel inang yang mengandung DNA rekombinan yang diinginkan.

9. Penyimpanan gen hasil klon dalam perpustakaan DNA.

10. Memasukkan (mentransfer) perbanyakan gen hasil rekombinan yang telah dimurnikan tersebut ke dalam masing-masing telur atau sperma ikan yang dipilih sebagai ikan transgenik.

11. Pembuahan buatan dengan menggabungkan telur dan sperma tersebut pada wadah tertentu dalam media air.

\section{Metode Transfer Gen}

Sejak ditemukannya struktur DNA oleh Watson \& Crick pada tahun 1953, kemudian mulai berkembanglah teknologi rekayasa genetika pada tahun 1970-an dengan tujuan untuk membantu menciptakan produk dan organisme baru yang bermanfaat. Sejarah membuktikan bahwa teknik rekayasa genetika terus-menerus mengalami perkembangan dan penyempurnaan dari metode-metode sebelumnya. Adapun metode-metode yang telah berhasil diterapkan dalam teknologi transfer gen antara lain adalah:

\section{Mikroinjeksi}

Telur yang telah dibuahi dalam beberapa saat (sesuai perkembangan telur untuk setiap jenis ikan, umumnya pada saat perkembangan 2 sampai 4 sel, dilakukan transfer gen menggunakan mikroinjeksi. Penyuntikan gen berikut promoter dapat dilakukan ke dalam inti zigot atau sitoplasma. Sesungguhnya pada telur ikan, penyuntikan gen ke dalam inti zigot menunjukkan hasil yang lebih baik dibanding penyuntikan gen ke dalam sitoplasma. Akan tetapi inti zigot sangat kecil dan sangat tidak mungkin terlihat, sehingga gen selalu disuntikkan ke dalam sitoplasma dekat dengan inti. Kemudian setelah itu, di dalam inti, gen diharapkan mengalami penggabungan (integration) ke dalam salah satu kromosom. Penggabungan ini merupakan hal yang penting karena dengan terjadinya hal ini gen dapat diturunkan dari ikan transgenik kepada turunannya. Transfer gen melalui teknik mikroinjeksi mempunyai banyak kelemahan, karena teknik membutuhkan keterampilan yang tinggi. Efek dari teknik ini telur yang sedang diperlakukan terganggu sehingga tingkat keberhasilan kecil. Selain itu, hasil yang didapatkan tidak bisa banyak, mengingat pengerjaan yang manual satu per satu telur pada pembelahan satu sel diinjeksi. Percobaan transfer gen GFP terhadap ikan komet melalui metode mikroinjeksi yang telah dicobakan di Balai Penelitian dan Pengembangan Budidaya Ikan Hias belum pernah berhasil sampai mendapatkan individu founder. Hal tersebut disebabkan 
banyaknya kesulitan dan hambatan seperti yang dikemukakan oleh Khoo et al. (1992) dan Chen (1994):

1. Memasukkan jarum mikroinjeksi ke dalam mikropil

2. Jarum mikroinjeksi sulit menembus korion telur komet yang agak keras

3. Perlu memindahkan cairan korion telur

4. Peralatan yang sangat mahal

5. Lambat dan cenderung menjemukan

\section{Elektroporasi}

Elektroporasi adalah sebuah metode yang pertama kali dikembangkan untuk bekerja dengan sel-sel dalam jaringan budaya dan menundukkan melibatkan sel untuk ledakan pendek impuls listrik. Keuntungan utama dari elektroporasi atas microinjection adalah bahwa ada tidak perlu menangani dan memanipulasi telur secara individual. Elektroporasi telah dicoba pada telur ikan, tetapi kesulitan adalah bahwa telur cukup besar dan memiliki korion. Prinsip metode ini adalah penggunaan secara singkat dan cepat rangsangan listrik untuk menembus membran sel, sehingga memungkinkan masuknya molekul DNA ke dalam embrio. Metode ini memberikan harapan keberhasilan transfer gen ikan yang digunakan. Selain praktis, memerlukan waktu yang tidak terlalu lama, dapat menggunakan telur maupun sperma sebagai vektornya. Chen (1994) mengemukakan metode ini pada ikan baru popular sekitar awal tahun 1990-an dan baru berhasil menghasilkan ikan transgenik pada tahun 1992, yang dilakukan oleh Lu pada ikan medaka dan Power pada ikan catfish, sedangkan metode ini dilakukan oleh Baekon tahun 2000. Selanjutnya metode ini dikembangkan dengan penggunaan sperma sebagai vector. Keberhasilan metode ini pertama kali dilakukan oleh Khoo et al. (1992) yaitu keberhasilan dalam penggunaan sperma ikan zebrafish (Brachydanio rerio), melalui pembuahan secara in vitro.

\section{Transfeksi}

Metode transfer gen yang bertujuan untuk pengujian aktivitas promoter salah satunya dengan metode transfeksi ke sel kultur (Kato et al., 2007). Pada metode ini yang diperlakukan adalah telur yang baru keluar dan sebelum terjadi pembelahan 1 sel. Sebagaimana metode transfer gen yang lain transfeksi ini juga diawali dengan isolasi plasmid konstruksi gen.

Teknik perlakuan metode tersebut pada umumnya mengacu pada protokol yang telah diuraikan pada bahan larutan transfeksi jetPEl (Polyplus Transfection) yang telah umum digunakan. Metode transfeksi lebih cocok digunakan untuk ikan yang mempunyai ukuran telur kecil, korion tipis dan daya tetas tinggi seperti halnya udang. Jumlah telur yang diaplikasikan pada metode tersebut relatif lebih besar, tergantung kemampuan dan keahlian dalam penyediaan telur dalam jumlah banyak dan waktunya singkat (Parenrengi, 2010).

\section{Karakterisasi Ikan Transgenik}

Keberhasilan transfer gen atau penyisipan gen pada telur maupun sperma ikan tersebut (ekspresi) dapat diidentifikasi mulai dari perkembangan telur dengan mikroskop flouresen. Tahapan karakterisasi terhadap ikan-ikan hasil transfer gen meliputi beberapa yang membutuhkan ketelitian, keterampilan, dan cukup banyak menyita waktu. Hal-hal yang diperlukan pada tahap ini adalah:

1. Identifikasi individu yang diduga berhasil sebagai ikan transgenik.

2. Identifikasi apakah benar telah mengalami penggabungan dengan genom ikan (host genom).

3. Identifikasi apakah sifat genetiknya diturunkan pada F-1 keturunannya.

4. Identifikasi ekspresi (kenampakan) dari produk gen tersebut secara fenotip apakah sesuai dengan yang diharapkan.

Identifikasi penentuan ikan transgenik dilakukan dengan dot blot dan shorthern blot hybridization dari genomic DNA. Kemudian identifikasi tersebut dikembangkan dengan menggunakan PCR, yang diambil dari jaringan sirip. Amplifikasi PCR dari urutan gen yang ditransfer dan analisis Southern blot untuk amplifikasi produk dari gen, menghasilkan analisis yang cukup sensitif dan cepat untuk dapat mendeteksi ribuan ikan yang diduga sebagai ikan transgenik. Untuk ekspresi gen yang ditransfer umumnya dideterminasi melalui pengukuran suatu produksi dari masing-masing mRNA melalui nothern RNA blot hybridization, RNA protein assay atau RT-PCR atau mengukur masing-masing produk gen melalui immunichemical (Subagyo, 2000). Secara umum yang sering digunakan adalah immunochemical seperti radio imunoassay dan western immunoblot anaysis (Chen, 1994).

\section{PENUTUP}

Teknologi transgenik dalam bidang akuakultur di masa mendatang memiliki prospek yang sangat cerah terutama dalam memproduksi benih ikan-ikan yang memiliki potensi tumbuh, seperti: efisiensi pemanfaatan pakan yang tinggi, ketahanan terhadap stres dan penyakit, dan mampu beradaptasi pada perubahan lingkungan yang luas. 
Ke semua hal tersebut sangat menunjang dalam upaya peningkatan produksi ikan-ikan budidaya.

Keberhasilan menghasilkan ikan hias transgenik melalui biologi molekuler dengan karakter keunggulan tertentu memberikan harapan baru dalam budidaya ikan khususnya dalam menunjang peningkatan kualitas warna dan bentuk. Meskipun rekayasa genetika bukan segalagalanya, karena adanya keterbatasan dalam menghasilkan ikan transgenik seperti badang yang bengkok, kepala bercabang, dan lain-lain.

\section{DAFTAR ACUAN}

Alimuddin, Yoshizaki, G., Carman, O., dan Sumantadinata, K. 2003. Aplikasi transfer gen dalam akuakultur. Jurnal Akuakultur, 2(1): 40-51.

Blake, A. 2007. Rekayasa genetika. http//:www/rekayasa genetika/l

Chen, T.T. 1994. Gene Transfer and Transgenic Fish: Molecular and physiological approach the action of growth hormone. In Chou, L.M., Munro, A.D., Lam, T.J., Chen, T.W., Cheong, L.K.K., Ding, J.K., Hooi, K.K., Koo, H.W., Phang, V.P.E., Shim, K.F., \& Tan, C.H. (Eds.) The third Asian Fisheries Forum. Asian Fisheries Society, Manila, Philippines, p. 584-590.

Glick, B.R. \& Pasternak, J.J. 2003. Molecular Biotechnology. Principle and Application of Recombinant DNA. Washington. ASM Press, $153 \mathrm{pp}$.

Kato, K., Tagaki, M., Tamaru, Y., Akiyama, S.I., Konishi, T., Murata, O., \& Kumai, H. 2007. Construction of an expression vector containing a $\beta$-actin promoter region for gene transfer by microinjection in red sea bream Pagrus major. Fish Sci., 73: 440-445.

Khoo, H.W., Ang, L.H., Limand, H.B., \& Wong, K.Y. 1992. Sperm cells as vectors for introducing forign DNA into zebra fish. Aquaculture, 107: 1-19.

Ozato, K., Inoue, K., \& Wakamatsu, Y. 1989. Transgenic fish: biologycal and technical problems. Zoological Science, 6: 445-457.

Parenrengi, A. 2010. Peningkatan Resistensi Udang Windu Penaeus monodon terhadap Penyakit White Spot Syndrome Virus melalui Transfer Gen Penaeus Monodon Antiviral. Disertasi. IPB, $113 \mathrm{hlm}$.

Pinkert, C.A. 1994. Transgenic Animal Technology. Academic Press, Inc., New York, p. 297-313.

Subagyo. 2000. Ikan Transgenik (transgenic fish): trend baru rekayasa genetika dalam budidaya ikan. Universitas Indonesia. Jakarta, $15 \mathrm{hlm}$.

Tsai, H.J. 2008. Use of Transgenic Fish Possessing Special Genes as Model Organisms and Potential Applications. Journal of Genetics and M olecular Biology, 19(1): 22-38.

Yan, S.Y. \& Özgünen, T. 1993. Fish breeding and biotechnology. Journal of Islamic Academy of Sciences, 6(3): 220242.

Zhu, Z., Li, G., He, L., \& Chen, S. 1985. Novel gene transfer into the fertilized eggs of gold fish (Carassius auratus L. 1758). Z. Angew.Ichthyol., 1: 31-34. 